\title{
Tévhitek az orvosi kommunikációról
}

\author{
Sándor Imola • Pilling János dr. \\ Semmelweis Egyetem, Általános Orvostudományi Kar, Magatartástudományi Intézet, Budapest
}

\begin{abstract}
Napjainkban az orvosi kommunikáció jelentőségét számos kutatási eredmény bizonyítja, a mindennapi gyakorlatban mégis gyakran találkozunk ezekkel ellentétes mítoszokkal, tévhitekkel, az ezekbő́l fakadó kedvezőtlen attitűddel. Mindez megakadályozza a valódi szemléletváltást és a betegközpontú ellátás irányába történő elmozdulást. A szerzők arra vállalkoztak, hogy bemutassanak néhány gyakori tévhitet, s az ezekkel kapcsolatos kutatási eredményeket. Orv. Hetil., 2016, 157(17), 644-648.
\end{abstract}

Kulcsszavak: orvosi kommunikáció, tévhitek, betegcentrikus szemlélet

\begin{abstract}
Misbelieves about medical communication
Despite a growing body of evidence about the importance of good communication skills in healthcare, every day practice shows several common myths or false believes about it. In the opinion of the authors these misbelieves are often behind doctors' or students' negative attitudes, which hinder the quality improvement or shift towards patientcentered approach. The scope of this article is to present the most frequently heard misbelieves from our empirical experiences in line with the evidence derived from current research data.
\end{abstract}

Keywords: medical communication, misbelieves, patient-centered healthcare

Sándor, I., Pilling, J. [Misbelieves about medical communication]. Orv. Hetil., 2016, 157(17), 644-648.

(Beérkezett: 2016. február 26.; elfogadva: 2016. március 17.)

A korszerű, XXI. századi gyógyítómodell középpontjában a beteg áll. Bár sokféle meghatározással találkozunk ezt a szemléletet illetően $[1,2]$, bármelyiket is vesszük alapul, az orvos-beteg kommunikáció szerepének hangsúlyozását mindegyikben megtaláljuk. Az utóbbi évtizedekben számos bizonyíték gyúlt össze annak alátámasztására, hogy a kapcsolati készségek - és ezeken belül a kommunikáció minősége - jelentősen befolyásolják a betegek elégedettségét, együttmúködését, a gyógyulás kimenetelét, de akár a múhibaperek gyakoriságát is $[3,4]$.

Mindezen ismeretek hatására a világ számos egyetemén a kommunikáció oktatása, fejlesztése az orvosképzés részévé vált. A képzések jellege, időtartama intézményenként különböző, ám egyes egyetemeken a hallgatók gyakran a teljes tanulmányi időszakon átívelő kommunikációfejlesztésen vesznek részt. Az oktatás céljairól, a gyakorló orvosok számára elsajátítandó kommunikációs készségekről az Amerikai Egyesült Államokban, Kanadában és Európában is konszenzusnyilatkozatokat adtak ki [5-7]. A kommunikációoktatás curriculumba foglalása azt az üzenetet hordozza, hogy ezek a készségek a pálya- alkalmasság elengedhetetlen velejárói, és ugyanolyan fontosak a gyógyítói kompetencia szempontjából, mint a szomatikus szakismeretek és a technikai készségek.

Magyarországon az orvostanhallgatók 1993 óta részesülnek kommunikációs képzésben, amely egy féléven keresztül, heti 2 órában zajlik. Kedvező előrelépés, hogy a kommunikációoktatás immár a rezidensképzésnek is kötelező részévé vált. Mindemellett a már végzett orvosoknak is van lehetőségük posztgraduális képzés keretei között kommunikációs készségfejlesztésben részesülni.

A téma fontossága ellenére az orvosok és az orvostanhallgatók attitűdjei a kommunikáció szerepével, tanulhatóságával, jelentőségével kapcsolatban meglehetősen eltérôek. Véleményünk szerint ennek hátterében gyakran azok a tévhitek és hiedelmek is állhatnak, amelyek szilárdan tartják magukat a bizonyítékok ellenére, megakadályozva a kedvezőtlen attitüdök változását.

Tanulmányunkban bemutatunk néhány gyakori tévhitet és hiedelmet, majd a szakirodalom segítségével ismertetjük az ezekkel kapcsolatos kutatási eredményeket. Az orvosi kommunikációt befolyásoló tévhitek és hiedelmek témakörének szakirodalma meglepően csekély. Bár szá- 
mos tanulmány utal negatív attitüdökre, kevés írás foglalkozik ezek hátterével $[8,9]$, ezért a gyújtésben elsősorban a több évtizedes oktatói tapasztalatainkra hagyatkozunk.

\section{Tévhitek és hiedelmek}

A tévhit valamely dolog téves felfogását jelenti, míg a $h i$ edelem a tudományos bizonyítékokat nélkülöző elképzelésre utal. A különbség a kettő között tehát az, hogy míg a tévhitek egyértelmúen tévedésen alapulnak, addig a hiedelmeknek van/lehet némi valós alapjuk, ám eltúlzottak, és szélsőséges formájukban hamisak.

Az orvosi kommunikációval kapcsolatos leggyakoribb tévhiteknek és hiedelmeknek két csoportját különíthetjük el: léteznek az orvosi kommunikációt érintő általános tévhitek, hiedelmek (például: „A jó kommunikációra majd megtanít a mindennapi gyakorlat") és a kommunikáció speciális területeihez tartozók (például: „Az öngyilkossági késztetésre nem szabad nyíltan rákérdezni, mert ezzel ötletet adunk"). Ebben a cikkben a terjedelmi korlátok miatt csak az orvos-beteg kommunikáció jelentôségével és oktatásával kapcsolatos leggyakoribb tévhiteket mutatjuk be.

\section{„Kommunikálni mindenki tud, ezt nem kell tanulni”}

Egy 2011-es vizsgálat szerint a magyar orvostanhallgatók gyakorlati kommunikációs képzésük kezdetén nagyrészt egyetértenek azzal, hogy „Ahhoz, hogy jó orvos legyek, jó kommunikációs készségekkel kell rendelkeznem" (ötfokú skálán 4,44-os átlag), ám ennek ellenére nagyon megoszlik a véleményük a kommunikáció oktatásának fontosságáról („Úgy gondolom, nagyon hasznos kommunikációs készségeket tanulni az orvosképzésben": 3,47-os átlag). Saját kommunikációs készségeiket ugyanis a hallgatók (ugyanezen vizsgálat szerint) általában kitünőnek vagy jónak tartják [10].

Híressé vált, számos területen idézett vizsgálatukban Dunning és Kruger arra mutattak rá, hogy minél kevesebbet tud valaki egy adott területről, annál egyszerúbbnek gondolja azt, s egyúttal jelentősen felülbecsüli saját képességeit is ezen a területen [11]. Ezen a lélektani mechanizmuson alapul az a hiedelem is, hogy a kommunikációt nem szükséges tanulni.

Valójában a mindennapi kommunikációs készségek nem elegendőek az orvosi gyakorlathoz. A betegek terápiás együttmúködésével kapcsolatos kutatásokat áttekintő metaanalízis szerzői például rámutatnak arra, hogy közel kétszeresére növeli a beteg megfelelő együttmúködésének valószínűségét, ha orvosa kommunikációs képzésben részesült [3]. Másrészt azért is hibás az a feltételezés, hogy a hétköznapi kommunikációs készségek elegendőek, mert egy gyakorló orvosnak speciális kommunikációs problémákat kell megoldania. A hétközna- pok nem készítenek fel valakit mondjuk arra, hogy halálhírt közöljön egy gyermekét elveszített szülővel, meggyőzzön egy kényszerrel pszichiátriára szállított beteget arról, hogy most kórházban kell maradnia, jogszerúen, ám mégsem félelemkeltően beszéljen az orvosi kezelések kockázatairól, vagy értékelni tudja az öngyilkossági veszélyeztetettség kommunikációs jeleit. Ezek az ismeretek napjainkban már részei az orvosi kommunikáció oktatásának [12].

\section{„A kommunikációt nem lehet tanulni, a jó kommunikációs készség egy adottság, ami vagy van valakinek, vagy nincs”}

Kommunikációs készségeinket születésünktől fogva tanulás útján sajátítjuk el. Szüleink, tanáraink, kortársaink, munkatársaink, a média egyaránt befolyásolják a kommunikációnkat, amely így életünk során sokat változik.

Más készségekhez hasonlóan természetesen a kommunikáció is fejleszthető. Ezt igazolja többek között az a vizsgálat, amelyet három amerikai egyetemen párhuzamosan végeztek, amikor a közös elveken alapuló kommunikációoktatást egyidejűleg vezették be az orvosképzésbe. A képzés indítását megelőző évben felmérték az akkori harmadéves orvostanhallgatók kommunikációs készségeit, majd ugyanezt tették a következő évben azokkal a harmadéves hallgatókkal is, akik elvégezték az első kommunikációs képzést. A vizsgálat során standardizált pácienssel végzett klinikai interjúkat rögzítettek videóra, s a felvételeket egy kommunikációs készségeket leíró skála segítségével elemezték. Eredményeik szerint a kommunikációoktatásban részesült orvostanhallgatók a kapcsolatépítéstől kezdve az anamnézis felvételén át a terápiás lehetőségek megbeszéléséig több területen is szignifikánsan jobb kommunikációs teljesítményt nyújtottak, mint a képzésben még nem részesült társaik [13].

Már egy rövid, csupán 8 oktatási órából álló kommunikációs képzés is mérhető, pozitív hatásokat eredményezhet. Orvos-beteg beszélgetések hangfelvételeit a Roter Interaction Analysis System (RIAS) alapján értékelve kimutatható volt, hogy az egynapos kommunikációs képzésen részt vett orvosok hatékonyabban kommunikáltak a betegeikkel. A képzés hatása még a páciensek körében is kimutatható volt: a jobb orvosi kommunikáció következtében a betegek is pozitívabban reagáltak az orvos mondataira, s elégedettebbek voltak az orvosaikkal [14].

Természetesen sokat számít a képzés jellege, minősége is. Egy korábbi, vizsgálatokat szintetizáló tanulmány eredményei szerint a csupán előadásokból álló képzések nem elég hatékonyak, gyakran nem fejtenek ki megfelelő hatást az orvosok későbbi viselkedésére. A klinikai gyakorlatban is megjelenő változások eléréséhez az oktatásnak részben vagy teljes mértékben interaktívnak kell lennie [15]. 
Egy áttekintő tanulmányban 83 vizsgálat adatait öszszegezték az orvosi kommunikációs képzések hatékonyságával kapcsolatban. Ezek között egyetlen vizsgálat akadt, amelyben nem találtak változást a képzést követően a kommunikációban (ebben az esetben egy csupán 3 órás képzés hatásait vizsgálták). 82 kutatás azonban egybehangzóan azt igazolta, hogy a képzéseknek mérhető pozitív hatásaik vannak, amelyek egyaránt megjelennek az orvosok kommunikációjában és az orvos-beteg kapcsolatban is [16].

\section{„Az orvos szakmai tudásának fontossága mellett eltörpül a kommunikáció jelentösége”}

„És most, a szakmai előadások után betekintést nyerhetünk egy másik területre, az orvosi kommunikáció világába." Szakmai rendezvényeken orvosi kommunikációról szóló előadások felkonferálása előtt gyakran hangzik el a fentihez hasonló mondat, amely azt sugalmazza, hogy az orvosi kommunikáció nem szerves része a szakmaiságnak, és ezáltal a gyógyításban a jelentősége csekélyebb, mint az egyéb kompetenciáké. A köztudatban tehát gyakran tetten érhető valamiféle rangsorolás a különféle gyógyítói készségek fontosságát illetően, amelyben a kommunikáció rendszerint hátrasorolódik. Ennek a hátterében ott lehet természetesen, hogy az évtizedekig domináló biomedikális szemlélet sokkal nagyobb hangsúlyt fektetett a technikai tudásra, mint a kommunikációra. Napjainkban azonban a kutatási eredmények más színezetet adnak mindennek.

Stewart szakirodalmi áttekintőjében 21 vizsgálatból 16-ban talált szignifikáns együttjárást a kommunikáció és a betegség kimenetele között [17]. Mindezt olyan élettani paraméterek is alátámasztották, mint a vérnyomásérték, vércukorszint vagy a fájdalomtűrés. Egy kutatás szerint például az orvos világos magyarázata, a betegek aktív részvételre buzdítása, döntésbe vonása kedvezőbb vérnyomásértékkel járt [18]. Egy másik vizsgálat szerint azoknál a cukorbetegeknél, akiknél a nővér úgynevezett irányító kommunikációt használt (például félbeszakította a beteget, direktív módon utasított, ellentmondott), szignifikánsan rosszabb anyagcsere-paramétereket mértek, mint azoknál a betegeknél, akikkel a nővér betegközpontúan kommunikált [19]. Heisler és mtsai vizsgálatukban arra keresték a választ, hogy 2 -es típusú diabeteses betegek és orvosaik között milyen az egyetértés a kezelés céljára és tervére vonatkozóan, illetve ez mennyire befolyásolja a betegség kontrollját (vagyis azt, hogy a beteg maga menedzseli cukorbetegségét) [20]. Az eredmények rámutattak arra, hogy az orvosok elképzelései a kezelésre vonatkozóan csak nagyon kevéssé voltak összhangban a páciensekével. Ugyanakkor a megfelelő kommunikációval javítható összhang mértéke bizonyítottan együtt járt a páciensek énhatékonyságának fokozódásával, betegségük jobb kontrolljával. Egy metaanalízis szerzői pedig arra mutattak rá, hogy az úgynevezett motivációs interjú technikáinak a használata pozitív ha- tást gyakorol többek között a vérnyomás- és a vérzsírszintkezelés jól mérhető eredményeire [21].

Ma már tehát nem az a kérdés, hogy az orvos kommunikációja hatással van-e a betegség kimenetelére, hanem az, hogy a kommunikáció milyen tényezőkön keresztül fejti ki a hatását. Street és mtsai „Hogyan gyógyít a kommunikáció?" címú áttekintő munkájukban az ezzel kapcsolatos vizsgálatokat veszik sorra [22]. Megállapításaik szerint az orvos kommunikációja több szinten is hozzájárulhat a gyógyítás hatékonyságának fokozódásához. A megfelelő kommunikáció hatására többek között javulnak a betegek ismeretei a betegségről és annak kezeléséről, nő az orvosba vetett hitük, jobban egyetértenek orvosaikkal a kezelési tervet illetően, javulnak az önmenedzselési képességeik, jobb lesz a betegség feletti kontrolljuk, s mindezekkel együtt jobb lesz a terápiás együttmüködésük.

A gyógyítómunka eredményességének, a szakmai kompetenciának tehát alapvető eleme az orvos megfelelő kommunikációja. A betegközpontú ellátásban az orvospáciens kapcsolat minősége meghatározó, s ennek a „vivőanyaga" éppen maga a kommunikáció. Fontos tehát integratív módon szemlélni a professzionális kompetenciákat, amelyeknek szerves részei a kommunikációs, kapcsolati készségek $[23,24]$.

\section{„Az orvosi kommunikációval kapcsolatos ismeretek inkább szubjektí véleményeken alapulnak, nem bizonyitékokon”}

Az utóbbi időben nagyon sok bizonyíték gyưlt össze a kommunikáció jelentőségével, szakszerű alkalmazásának lehetőségeivel kapcsolatban, sőt ma már kijelenthető, hogy konszenzus is van a gyógyításban betöltött szerepét illetően, mégis gyakran találkozni a fenti kijelentéssel [25]. Mindmáig sokan úgy vélik, hogy az orvosi kommunikációs képzések az oktatók saját tapasztalatainak, véleményeinek az átadását jelentik. Valójában - amint jelen tanulmányunk eddigi részei is jól jelzik - az orvosi kommunikáció területén intenzív kutatások zajlanak, így a minőségi orvosi kommunikációs oktatás bizonyítékon alapuló ismeretekre és készségekre taníthatja meg az orvostanhallgatókat és a gyakorló orvosokat.

A kutatások kezdetben az orvos-beteg kapcsolat leggyakoribb elemeire irányultak, mint amilyenek az anamnézis felvételének kommunikációs technikái, az aktív figyelem, a kétirányú kommunikáció, az empátiás törődés, a személyre szabott tájékoztatás, a betegoktatás. Ezeknek a témaköröknek a könyvtárnyi szakirodalmát ma már szakkönyvek foglalják össze [26, 27]. A továbbiakban előtérbe került a terápiás együttmúködés jelentősége, így a compliance, az adherencia javításának kommunikációs kérdéseiról indultak kutatások, majd jelentek meg review tanulmányok és metaanalízisek $[3,28]$. Ennek kapcsán került reflektorfénybe a közös döntéshozatal mechanizmusa [29], a motivációs interjú szemléletének és haté- 
kony módszereinek használata a szomatikus orvoslásban [21]. Ma már az orvos-beteg kommunikáció résztémaköreinek is szinte beláthatatlan mennyiségú szakirodalma van. Napjainkban előtérbe került az egészségmúveltség témaköre (health literacy: az egészségügyi információk megszerzésének, megértésének és a mindennapi gyakorlatban való használatának képessége), különös tekintettel az alacsony egészségmûveltségű emberekkel folytatott kommunikációra [30], valamint hangsúlyossá váltak a betegbiztonság kommunikációs vonatkozásai [31].

\section{„Szép dolog ez a kommunikáció, de nincs nekünk erre idönk"}

Az orvosi kommunikáció a témakört kevésbé ismerők számára gyakran a pácienssel való hosszas beszélgetés, „csevegés” szinonimája. Amint már a fentiekből is láthattuk, az orvosi kommunikáció sokkal inkább hatékony módszerek, technikák tárháza. Ám ha ez így is van, az orvosoknak jut-e idejük ezek alkalmazására?

A témakörben készült szakirodalmi áttekintés rámutat arra, hogy a vizsgálatok szerint nincs különbség az orvoscentrikus és a betegcentrikus vizitek hosszában [32]. Ami sokkal inkább számít, az a találkozás minősége. Egy közelmúltban megjelent vizsgálat eredménye szerint például a kézsebészeti vizittel való elégedettség független volt a találkozás beteg által érzékelt időtartamától - a páciens elégedettségét tehát nem ez határozta meg, hanem az, hogy mennyire érezte empatikusnak a sebészt [33].

Valójában gyakran éppen a mindennapokban használt kommunikációs megközelítések időrablók. Sok orvos szóban hosszan magyaráz a pácienseinek. A rövid távú memória átlagos befogadóképessége azonban csupán $7 \pm 2$ információegység, az ily módon átadott információk nagy része tehát elvész - a beteg gyakran már a rendelő ajtajában sem emlékszik vissza arra, hogy mit mondott neki az orvos. A páciens ismeretszintjének felmérése és az ennek megfelelő tájékoztatás, a kérdezés lehetőségének biztosítása, a betegtájékoztatók használata, a hiteles honlapok ajánlása hatékonyabb, s gyakran időtakarékosabb módja a betegtájékoztatásnak, mint a nagyon hosszú magyarázat. Hasonlóképpen, a páciens együttmúködésének javítása érdekében a hosszas rábeszélés, győzködés sok időt vesz igénybe, s gyakran hatástalan. Az úgynevezett viselkedésváltozás szakaszainak modellje abban segítheti az orvost, hogy célzottan, annak a szakasznak megfelelően kommunikáljon a betegével, amelyikben a beteg tart, s így rövidebb idő alatt is hatékonyabb lehet a kommunikációja [34]. Az orvosi kommunikáció módszerei tehát valójában inkább abban tudják segíteni a gyakorló orvosokat, hogy a rendelkezésükre álló rövid időt hogyan tudják minél hatékonyabban hasznosítani.

\section{Következtetések}

Az orvosi kommunikációval kapcsolatos vizsgálatok robbanásszerü fejlődésének köszönhetően számtalan bizonyíték gyúlt össze ahhoz, hogy újragondoljuk a témával kapcsolatos korábbi nézeteket. Ma már evidenciának számít, hogy a jó kommunikáció a gyógyítói kompetencia szerves része, a pályaalkalmasság mutatója. Nagyon sok ismeretünk van a hatékony kommunikáció technikáiról, módszereiról, arról, hogy mindezek hogyan fokozzák a betegek együttmúködését, énhatékonyságát, a gyógyulás kimenetelét [35, 36]. Érdekes kérdés természetesen, hogy pontosan milyen hatásmechanizmusokon keresztül történik mindez, amelynek megválaszolásához további vizsgálatokra van még szükség [22].

A vizsgálatokból egyértelműen kirajzolódik az is, hogy a kommunikációs képzések hatására megváltoznak a gyógyítók attitűdjei a páciensközpontú orvoslással kapcsolatban, s ez a változás fontos háttértényezőnek bizonyul a készségek gyakorlati alkalmazásánál. Ezen készségek formálásához bizonyítottan hatékony oktatási módszerek állnak ma már rendelkezésre, amelyek viszonylag rövid idő alatt is kimutathatóan pozitív változást eredményeznek az orvos-beteg kommunikációban [37].

Anyagi támogatás: A közlemény megírása, illetve a kapcsolódó kutatómunka anyagi támogatásban nem részesült.

Szerzői munkamegosztás: A tanulmány struktúrájának kidolgozásában, a szakirodalom feldolgozásában, a kézirat megszövegezésében mindkét szerző részt vett. A kézirat végleges változatát a szerzők elolvasták és jóváhagyták.

Érdekeltségek: A szerzőknek nincsenek érdekeltségeik.

\section{Irodalom}

[1] Stewart, M.: Patient-centered medicine: transforming the clinical method. Radcliffe Publishing, Abingdon, 2003.

[2] Mead, N., Bower, P.: Patient-centredness: a conceptual framework and review of the empirical literature. Soc. Sci. Med., 2000, 51(7), 1087-1110.

[3] Zolnierek, K. B., DiMatteo, M. R.: Physician communication and patient adherence to treatment: a meta-analysis. Med. Care, $2009,47(8), 826-834$.

[4] Adamson, T. E., Tschann, J. M., Gullion, D. S., et al.: Physician communication skills and malpractice claims. A complex relationship. West J. Med., 1989, 150(3), 356-360.

[5] Simpson, M., Buckman, R., Stewart, M., et al.: Doctor-patient communication: the Toronto consensus statement. BMJ, 1991, 303(6814), 1385-1387.

[6] Brunett, P. H., Campbell, T. L., Cole-Kelly, K., et al.: Essential elements of communication in medical encounters: the Kalamazoo consensus statement. Acad. Med., 2001, 76(4), 390-393.

[7] Bachmann, C., Abramovitch, H., Barbu, C. G., et al.: A European consensus on learning objectives for a core communication curriculum in health care professions. Patient Educ. Couns., 2013, 93(1), 18-26. 
[8] Back, A., Baile, W.: Communication skills: myths, realities and new developments. J. Support Oncol., 2003, I(3), 169-171.

[9] Devengele, M.: Communication training: Skills and beyond. Patient. Educ. Couns., 2015, 98(10), 1287-1291.

[10] Tóth, I., Bán, I., Füzesi, Z., et al.: Attitudes of freshman medical students towards education in communication skills. [Első évfolyamos orvostanhallgatók attitüdjei az orvosi kommunikáció oktatásával kapcsolatban.] Orv. Hetil., 2011, 152(38), 1535-1543. [Hungarian]

[11] Kruger, J., Dunning, D.: Unskilled and unaware of it: how difficulties in recognizing one's own incompetence lead to inflated self-assessments. J. Pers. Soc. Psychol., 1999, 77(6), 1121-1134.

[12] Pilling, J. (ed.): Medical communication. [Orvosi kommunikáció.] Medicina Könyvkiadó, Budapest, 2008. [Hungarian]

[13] Yedidia, M. J., Gillespie, C. C., Kachur, E., et al.: Effect of communications training on medical student performance. JAMA, 2003, 290(9), 1157-1165.

[14] Roter, D., Rosenbaum, J., de Negri, B., et al.: The effects of a continuing medical education programme in interpersonal communication skills on doctor practice and patient satisfaction in Trinidad and Tobago. Med. Educ., 1998, 32(2), 181-189.

[15] Davis, D., O'Brien, M. A., Freemantle, N., et al.: Impact of formal continuing medical education: do conferences, workshops, rounds, and other traditional continuing education activities change physician behavior or health care outcomes? JAMA, 1999, 282(9), 867-874.

[16] Aspegren, K.: BEME Guide No. 2: Teaching and learning communication skills in medicine - a review with quality grading of articles. Med. Teach., 1999, 21(6), 563-570.

[17] Stewart, M. A.: Effective physician-patient communication and health outcomes: a review. CMAJ, 1995, 152(9), 1423-1433.

[18] Orth, J. E., Stiles, W. B., Scherwitz, L., et al.: Patient exposition and provider explanation in routine interviews and hypertensive patients' blood pressure control. Health Psychol., 1987, 6(1), $29-42$.

[19] Street, R. L. Jr., Piziak, V. K., Carpentier, W. S., et al.: Providerpatient communication and metabolic control. Diabetes Care, 1993, 16(5), 714-721.

[20] Heisler, M., Vijan, S., Anderson, R. M., et al.: When do patients and their physicians agree on diabetes treatment goals and strategies, and what difference does it make? J. Gen. Intern. Med., 2003, 18(11), 893-902.

[21] Rubak, S., Sandbaek, A., Lauritzen, T., et al.: Motivational interviewing: a systematic review and meta-analysis. Br. J. Gen. Pract., 2005, 55(513), 305-312.

[22] Street, R. L. Jr., Makoul, G., Arora, N. K., et al.: How does communication heal? Pathways linking clinician-patient communication to health outcomes. Patient Educ. Couns., 2009, 74(3), 295-301.

[23] Esstein, R. M., Hundert, E. M.: Defining and assessing professional competence. JAMA, 2002, 287(2), 226-235.
[24] Von Fragstein, M., Silverman, J., Cushing, A., et al.: UK consensus statement on the content of communication curricula in undergraduate medical education. Med. Educ., 2008, 42(11), 1100-1107.

[25] Wright, K. B., Bylund, C., Ware, J., et al.: Medical student attitudes toward communication skills training and knowledge of appropriate provider-patient communication: a comparison of first-year and fourth-year medical students. Med. Educ. Online (serial online), 2006, 11, 18. Available from http://www.meded-online.org

[26] Silverman, J., Kurtz S. M., Draper, J.: Skills for communicating with patients. 2nd ed. Radcliffe Publishing, Oxford, 2005.

[27] Tate, P.: The doctor's communication handbook. Radcliffe Publishing, London, 2010.

[28] Vermeire, E., Hearnshaw, H., Van Royen, P., et al.: Patient adherence to treatment: three decades of research. A comprehensive review. J. Clin. Pharm. Ther., 2001, 26(5), 331-342.

[29] Shay, L. A., Lafata, J. E.: Where is the evidence? A systematic review of shared decision making and patient outcomes. Med. Decis. Making, 2015, 35(1), 114-131.

[30] Berkman, N. D., DeWalt, D. A., Pignone, M. P., et al.: Literacy and health outcomes. Agency for healthcare research and quality. 2004. http://www.ahrq.gov/clinic/tp/littp.htm.Rockville

[31] Manser, T.: Teamwork and patient safety in dynamic domains of healthcare: a review of the literature. Acta Anaesthesiol. Scand., 2009, 53(2), 143-151.

[32] Mauksch, L. B., Dugdale, D. C., Dodson, S., et al.: Relationship, communication, and efficiency in the medical encounter creating a clinical model from a literature review. Arch. Intern. Med., 2008, 168(13), 1387-1395.

[33] Parrish, R. C. 2nd, Menendez, M. E., Mudgal, C. S., et al.: Patient satisfaction and its relation to perceived visit duration with a hand surgeon. J. Hand Surg. Am., 2016, 41(2), 257-262.e4

[34] Prochaska, J. O.: Transtheoretical model of behavior change. In: Encyclopedia of behavioral medicine. Springer, New York, 2013.

[35] Maguire, P., Pitceatbly, C.: Key communication skills and how to acquire them. BMJ, 2002, 325(7366), 697-700.

[36] Beck, R. S., Daughtridge, R., Sloane, P. D.: Physician-patient communication in the primary care office: a systematic review. J. Am. Board Fam. Pract., 2002, 15(1), 25-38.

[37] Jenkins, V., Fallowfield, L.: Can communication skills training alter physicians' beliefs and behavior in clinics? J. Clin. Oncol., $2002,20(3), 765-769$.

(Sándor Imola, Budapest, Nagyvárad tér 4., 1089 e-mail: sandor.imola@med.semmelweis-univ.hu) 